\title{
Silent Cerebral Infarcts and Retinal changes in patients with Sickle cell Disease
}

\author{
Channa $\mathbf{U}^{1}$, Arya $\mathrm{S}^{2}$, Jain $\mathbf{H}^{3}$, Bhaisare $\mathbf{V}^{4}$ \\ ${ }^{1}$ Dr. Urvashi Channa, P.G. Student, Department of Pediatrics, ${ }^{2}$ Dr. Sunil Arya, Assistant Professor , Department of \\ Pediatrics, ${ }^{3}$ Dr. Hemant Jain, Professor, Department of Pediatrics, ${ }^{4}$ Dr. Vijay Bhaisare, Professor and Head, Department \\ of Ophthalmology, All are affiliated with M.G.M. Medical College,Indore (MP)
}

Address for Correspondence: E-mail: ${ }^{2}$ Dr. Sunil Arya, drsunilarya22@gmail.com

\begin{abstract}
Background: CNS Complications of SCD include headache, seizures, cerebral venous thrombosis, and strokes. $11 \%$ and $20 \%$ of children with sickle cell anaemia will have overt and silent strokes respectively before their 18th birthday. 14$20 \%$ of SCD patients will develop Sickle cell Retinopathy. Aim of study: To look for SCI and Retinal changes in SCD children. Design- Prospective Cross sectional study. Participants- Below 16 yrs in a tertiary care hospital MYH/CNBC Indore, MP. Method: 40 children with SCD < 16 years admitted to Department of Paediatrics, MYH / CNBC Hospital, Indore, from December 2014 to October 2015 were selected and underwent MRI evaluation of brain and fundus examination. Result: Only $6(15 \%)$ had presence of AV tortuosity with dialatation and $4(10 \%)$ had presence of SCI $(\mathrm{p}>0.05)$ out of 40 . All patients with SCI had presence of AV tortuosity $(p=0.001)$. Statistical Analysis: Kruskal wallis test was applied. Conclusion: 40 children with SCD below the age of 16 years were included, 4(10\%) had SCI and 6 (15\%) had AV tortuosity and dilatation of retinal vessels. Asymptomatic children of SCD with unanticipated silent infarcts are highly predictive of subsequent clinical stroke and progressive silent infarction. So, these patients should receive frequent blood transfusion to decrease the level of $\mathrm{HbS}$ and Hydroxyurea to increase the HbF levels to prevent further subsequent clinical stroke. Also these children should undergo regular ophthalmic checkup for retinal changes and evaluation by MRI Brain for early detection of cerebral infarcts to prevent future occurrence of stroke.
\end{abstract}

Keywords: Arteriovenous tortuosity, Sickle Cell Disease, Silent Cerebral Infarcts.

\section{Introduction}

Sickle cell disease is having multi-systemic complications, starting with a single base pair of DNA, at the 6th codon of the beta globin chain, which involves almost every system of human body [1]. In India, (Lehman and Kutbush, 1952) sickle cell anemia was first detected in tribes of Nilgiri hills, in Southern India after 42 years of its discovery by James Herrick. Later subsequent studies conducted by various workers confirmed high distribution of $\mathrm{HbS}$ gene in Central, Southern and North Eastern India. In certain states such as Madhya Pradesh, Chattisgarh, Maharashtra, Orissa, Jharkand and Gujarat it forms major public health problem. The signs and symptoms of sickle cell vary markedly both with time in the same individual and

Manuscript received: $13^{\text {th }} \mathrm{Feb} 2016$

Reviewed: $22^{\text {nd }} \mathrm{Feb} 2016$

Author Corrected; $01^{\text {st }}$ Mar 2016

Accepted for Publication: $10^{\text {th }}$ Mar 2016

between different individuals. Some people have mild symptoms while others have severe symptoms and are to be hospitalized for treatment. Pain is the most common complaint in children. It can be severe, acute or chronic, usually in the legs and lower back. Other symptoms include irritability, jaundice, aplastic crisis, acute chest syndrome, splenic and hepatic sequestration [2. In adolescence or adulthood, symptoms of childhood continue along with new symptoms like delayed puberty, severe joint pain, stroke, retinopathy, pulmonary hypertension, nephropathy. The pathophysiologic processes that lead to sickle cell disease related complications result from combination of haemolysis and vasoocclusion. The management of many complications of sickle cell disease continues to improve especially where neurologic complications remain a significant problem. CNS Complications include headache, seizures, cerebral venous thrombosis, and strokes. $11 \%$ and $20 \%$ of children with sickle cell 
anaemia will have overt and silent strokes respectively before their 18th birthday. Cognitive functions and fine motor skills are known to be affected in these patients [1]. $14-20 \%$ of Sickle cell disease patients will develop Sickle cell Retinopathy. Retinopathy is classified as either proliferative or nonproliferative. Retinopathy in sickle cell disease occurs due to arteriolar occlusion and ischemia of the peripheral retinal vasculature. Permanent vision loss is rare [3].

\section{Materials and Method}

Type of study - Prospective Cross Sectional Study

Place of study- The present study was conducted in diagnosed Sickle Cell Disease patients admitted to Department Of Pediatrics, MYH/CNBC Hospital, Indore, below the age of 16 years. This study was carried over for one year in Department Of Pediatrics, MYH/CNBC Hospital, Indore.

Sample size -40 cases
Source of data - The study includes children with sickle cell disease with age group $<16$ years in Department of Paediatrics MYH/CNBC Hospital, Indore.

Method- Children with sickle cell disease were evaluated by conducting MRI imaging of Brain (1.5 Tesla) and Fundus examination was conducted by Senior Consultant of Department of Ophthalmology to look for presence of Silent cerebral Infarcts and Retinal changes respectively. Results were interpretated using Kruskal Wallis test by using computerized SPSS system.

Inclusion Criteria

- All patients with sickle cell disease belonging to age of $<16$ years with no evidence of clinical stroke

Exclusion Criteria

- All Patients of sickle cell disease with evidence of clinical stroke.

- Those who were not giving consent.

\section{Result}

Maximum number of patients $12(37.5 \%)$ belonged to the age group between 8-12 years, 15(30\%) belonged to age group of less than 8 years, 13(32.5\%) belonged to age group 12-16 years. Maximum number of patients were male children $28(70 \%)$. Profile of sickle cell disease in our study maximum patients belonged to Sickle cell anemia that is $18(45 \%)$, Minimum constituted by Sickle with persistence of fetal $\mathrm{Hb} 6(15 \%)$.Patients constituted by Sickle $\beta+$ thalassemia, Sickle $\beta 0$ thalassemia were $9(22.5 \%)$ and $7(17.5 \%)$ respectively. All 40 patients were evaluated for retinal changes, only 6 (15\%) had presence of arteriovenous tortuosity with dialatation. $4(10 \%)$ had incidental findings of out of which 2 had pale disc, 1 patient had myopic fundus with atrophy and 1 had presence of bilateral papilledema. Fundus examination of rest of the $30(75 \%)$ patients was Normal. Out of 6 patients who had arteriovenous tortuosity 4 belonged to 12-16 years age group and 2 in 8-12 years age group and none in the age group less than 8 years. Out of 40 patients 4 had presence of silent cerebral infarcts that is $10 \%$ of the total. 36 patients $(90 \%)$ had no silent cerebral infarcts. Out of 36 patients who had no cerebral infarcts in MRI Brain, 4 had incidental findings that constituted $10 \%$ of the total. Small bifrontal haemorrhages in anterior paramedian frontal regions, arachnoid cyst, benign intracranial hypertension, Pachymeningitis with focal cerebritis in frontal region were observed in 1 patient each. Out of the 4 patients who had presence of silent cerebral infarcts 3 belonged to the age group 12-16 years and 1 belonged to the age group 8-12 years. Out of 6 patients who had arteriovenous tortuosity, all $4(100 \%)$ patients who developed silent cerebral infarcts were present in this group. Out of the 4 patients who developed silent cerebral infarcts, maximum that patients belonged to sickle cell anemia, and 1 that is belonged to sickle $\beta 0$ thalassemia. By application of Kruskal wallis test, Silent cerebral infarcts and retinal changes in patients with sickle cell disease was not found to be statistically significant. But relation between presence of silent cerebral infarcts in those patients with presence of arteriovenous tortuosity was found to be statistically significant ( $\mathrm{p}$ value of 0.001 )

Table No. 1: Age wise distribution of cases

\begin{tabular}{|l|l|l|}
\hline Age $($ years $)$ & $\begin{array}{l}\text { No. of Cases } \\
(\mathbf{n = 4 0})\end{array}$ & Percentage \\
\hline$<8$ years & 12 & $30 \%$ \\
\hline $8-12$ years & 15 & $37.5 \%$ \\
\hline$>12$ years & 13 & $32.5 \%$ \\
\hline
\end{tabular}

Table No. 2: Sex wise distribution of cases 


\begin{tabular}{|l|l|l|}
\hline Sex & $\begin{array}{l}\text { No. of cases } \\
(\mathbf{n = 4 0 )}\end{array}$ & Percentage \\
\hline Male & 28 & $70 \%$ \\
\hline Female & 12 & $30 \%$ \\
\hline
\end{tabular}

Table No. 3: Profile of sickle cell disease in our study

\begin{tabular}{|l|l|l|}
\hline Diagnosis & $\begin{array}{l}\text { Number of patients } \\
(\mathbf{n}=\mathbf{4 0})\end{array}$ & Percentage \\
\hline Homozygous Sickle cell anemia & 18 & $45 \%$ \\
\hline Sickle $\beta+$ thalassemia & 9 & $22.5 \%$ \\
\hline Sickle $\beta 0$ thalassemia & 7 & $17.5 \%$ \\
\hline Sickle with persistent fetal haemoglobin & 6 & $15 \%$ \\
\hline
\end{tabular}

Table No. 4: Retinal changes

\begin{tabular}{|l|l|l|}
\hline Fundal changes & $\begin{array}{l}\text { Total number of cases } \\
(\mathbf{n = 4 0 )}\end{array}$ & Percentage \\
\hline AV Tortuosity & 6 & $15 \%$ \\
\hline Others & 4 & $10 \%$ \\
\hline Normal & 30 & $75 \%$ \\
\hline
\end{tabular}

Table No. 5: Age wise distribution of fundus changes

\begin{tabular}{|l|l|l|l|}
\hline \multicolumn{2}{|c|}{ Total number of patients $(\mathbf{n}=\mathbf{4 0})$} & Presence of AV Tortuosity $(\mathbf{n}=\mathbf{6})$ & Percentage \\
\hline$<8$ years $\quad(\mathrm{n}=12)$ & 0 & $0 \%$ \\
\hline $8-12$ years $\quad(\mathrm{n}=15)$ & 2 & $33.33 \%$ \\
\hline $12-16$ years $\quad(\mathrm{n}=13)$ & 4 & $66.66 \%$ \\
\hline
\end{tabular}

Table No. 6: Presence of silent cerebral infarcts in present study

\begin{tabular}{|l|l|l|}
\hline MRI Brain Findings & Total $(\mathbf{n}=\mathbf{4 0})$ & Percentage \\
\hline Silent cerebral infarcts & 4 & $10 \%$ \\
\hline No Infarcts & 36 & $90 \%$ \\
\hline
\end{tabular}

Table No. 7: Distribution of silent cerebral infarcts in each age group

\begin{tabular}{|l|l|l|}
\hline $\begin{array}{l}\text { Age Groups wise distribution of } \\
\text { Cases } \\
(\text { total=40) }\end{array}$ & $\begin{array}{l}\text { Silent Cerebral Infarcts in MRI } \\
(\mathbf{n = 4})\end{array}$ & Percentage in each group \\
\hline$<8$ years & 0 & $0 \%$ \\
\hline $8-12$ years & 1 & $25 \%$ \\
\hline $12-16$ years & 3 & $75 \%$ \\
\hline
\end{tabular}

Table No. 8: Silent cerebral infarcts and AV tortuosity

\begin{tabular}{|c|c|c|c|}
\hline \multirow[b]{2}{*}{ MRI Brain $(n=40)$} & \multicolumn{3}{|c|}{ Fundus Findings $(n=40)$} \\
\hline & $\begin{array}{l}\text { AV Tortuosity } \\
(n=6)\end{array}$ & $\begin{array}{l}\text { Normal } \\
(n=30)\end{array}$ & $\begin{array}{l}\text { Others } \\
(n=4)\end{array}$ \\
\hline Silent Cerebral Infarcts $(n=4)$ & 4 & 0 & 0 \\
\hline No Infarcts $(n=36)$ & 2 & 30 & 4 \\
\hline$\%$ SCI in each group & $66.66 \%$ & $0 \%$ & $0 \%$ \\
\hline
\end{tabular}

\section{Discussion}


The present study was conducted in a tertiary care teaching hospital, Mahatma Gandhi Memorial Medical College associated Maharaja Yeshwant Rao and Chacha Nehru Bal Chikitsalaya Hospitals. Indore, surrounded by the sickle cell belt of Madhya Pradesh. The signs and symptoms of other common diseases overlap with the symptoms of SCD. Recurrent attacks of musculoskeletal pain, anemia, frequent respiratory infections, jaundice and splenomegaly are the typical features which should arouse suspicion of sickle cell disease. The present study is conducted to highlight the less frequently discussed Central Nervous System and Retinal complications in sickle cell disease patients. To look for the presence of silent cerebral infarcts and identify retinal changes in sickle cell disease patients.

A total of 40 children under 16 years of age were included during the study period. Among these children $28(70 \%)$ were males and $12(30 \%)$ were females. $45 \%$ had homozygous sickle cell disease, 22.5\% had coexisting thalassemia $\beta+, 17.5 \%$ had coexisting thalassemia $\beta 0,15 \%$ had coexisting hereditary persistence of fetal haemoglobin. In our study out of 40 patients that were evaluated for retinal changes only 6 $(15 \%)$ had presence of arteriovenous tortuosity with dialatation. $4(10 \%)$ had incidental findings of out of which 2 had pale disc, 1 patient had myopic fundus with atrophy and 1 had presence of bilateral papilledema. Fundus examination of rest of the 30 (75\%) patients was Normal. Out of 6 patients who had arteriovenous tortuosity $4(66 \%)$ belonged to $12-16$ years age group and 2(33\%) in 8-12 years age group and none in less than 8 years age group.

Only Arteriovenous tourtuosity was present in $15 \%$ of patients and no other features of sickle cell retinopathy was observed. AV tortuosity was found maximum in age group 12-16 years. No retinal changes were appreciated in patients less than 8 years. U.V Eruchalu et al found No child (aged 3 to 13 years) had ocular symptoms [5]. Retinal pathology was found only in patients over 8 years. Retinal lesions were found in 12 $(32.4 \%)$ of the children. The most common lesion was retinal infarcts $(14.9 \%)$, and choroidal infarct in 1 patient $(2.7 \%)$. Neovasclularization was observed in 2 patients $(5.4 \%)$. As per J. F. TALBOT et al in their study on Sickle cell retinopathy, Ophthalmological examinations were performed on 74 children, aged 5-7 retinal vessel abnormality, occurring in 30/59 (51\%) SS children and in 11/37 (30\%) SC children. Peripheral arteriolar closure was observed in 14 (24\%) SS children and in $6(16 \%) \mathrm{SC}$ children. Arteriovenous anastomoses were seen in 3 children, but proliferative retinopathy was not identified. The prevalence of peripheral vascular closure and retinal patches showed a significant upward trend with age.

Out of the 4 patients who had presence of silent cerebral infarcts 3 belonged to age group 12-16 years (75\%), $1(25 \%)$ to the age group of $8-12$ years, and none among less than 8 years age group. In our study we did not find any silent cerebral infarcts below age of 8 years, maximum infarcts were present in age group more than 12 years but it was not found to be statistically significant.

As per Charles T. Quinn et al Acute silent cerebral ischemic events were detected on $1.3 \%$ of MRIs (10 of 771 ) in 652 children (mean age, 10.0 years), with an incidence of 47.3 events per 100 patient-years (95\% CI, 22.7-87.2) [7]. As per R Grant Steen et al at mean age of 10 years, overall prevalence of infarction, ischemia, or atrophy in patients with SCD was $44 \%$ (82 of 185), and prevalence of vasculopathy was 55\% (102 of 185), in their study without evidence of a significant referral bias [8].

As per Thomas R. Kinney et al in their study among 42 patients (18.3\%) patient had silent cerebral infarcts [9]. In our study out of 6 patients who had arteriovenous tortuosity, all $4(100 \%)$ patients who developed silent cerebral infarcts were present in this group. And none in group with normal fundus or other fundus findings. The relation between silent cerebral infarcts and presence of AV tortuosity was found to be stastiscally significant with $p$ value of 0.001 . Maximum 3 patients with silent cerebral infarcts belonged to sickle cell anemia, and 1 belonged to sickle $\beta 0$ thalassemia and none in Sickle with persistence of fetal haemoglobin or Sickle $\beta+$ thalassemia group. Risk of development of silent cerebral infarcts was higher in patients with sickle cell anemia than in other sickle cell diseases but it was not found to be statistically insignificant.

Limitations: Due to small sample size data obtained was not found to be statistically significant.

\section{Conclusion}

The main objective of the study was to identify the Silent cerebral infarcts and retinal changes in children with sickle cell disease. Risk of development of silent 
cerebral infarcts is higher in Sickle cell anemia than in other sickle cell diseases.

Funding: Nill

Conflict of Interest: None

Permission of IRB: Yes

\section{References}

1. Nelson Textbook of paediatrics 19 th edition Chapter 456- Neurological complications of Sickle cell anemia pg no. 1666- 1667

2. Nathan and Oskis Haematology of Infancy and childhood 7th edition- Chapter 19th Sickle cell diseaseAcute CNS events pg no. 967- 969

3. Nathan and Oskis Haematology of Infancy and childhood 7th edition, Chapter 19th Sickle cell disease -Eyes- pg no. 976- 977

4. Talbot JF, Bird AC, Serjeant GR, Hayes RJ. Sickle cell retinopathy in young children in Jamaica. $\mathrm{Br} \mathrm{J}$

Ophthalmol. 1982 Mar;66(3):149-54.
5. UV Eruchalu et al (Ocular findings in children with severe clinical symptoms of homozygous sickle cell anemia in Kaduna,Nigeria) published in West African journal of Medicine Volume 25 No.2 (2006)

6. Thomas R. Kinney et al (Silent Cerebral Infarcts in Sickle Cell Anemia: A Risk Factor Analysis Department of Pediatrics, Duke Children's Hospital, Duke University Medical Center, Durham, North Carolina) published in American Academy of Paediatrics vol. 103 no. 3 640-645

7. R. Grant Steen et al(Brain Imaging Findings in Pediatric Patients with Sickle Cell Disease at St Jude Children's Research Hosp,LauderdaleSt, Memphis published in RSNA Radiology july 2003, Volume 228, Issue 1.

8. Quinn et al (Acute Silent Cerebral Ischemic Events in Children with Sickle Cell Anemia at tertiary care centers specializing in the treatment of children with Sickle cell anemia in the United States,England, and France.) Published in JAMA Neurol. 2013 January ; 70(1): 58-65. doi:10.1001/jamaneurol.2013.576

\section{How to cite this article?}

Channa U, Arya S, Jain H, Bhaisare V Silent Cerebral Infarcts and Retinal changes in patients with Sickle cell Disease

: Int J Pediatr Res 2016; 3(2):90-94.doi: $10.17511 /$ ijpr.2016.i02.04.

